EPJ Web of Conferences 98, 04003 (2015)

DOI: $10.1051 /$ epjconf/ 20159804003

(C) Owned by the authors, published by EDP Sciences - SIF, 2015

\title{
Bioenergy: Potentials and limitations
}

\author{
E.-D. Schulze and J. G. Canadell \\ Max-Planck Institute for Biogeochemistry - PO Box 1001 64, 07449, Jena, Germany and \\ Global Carbon Project, CSIRO Oceans and Atmospheric Flagship - Canberra, ACT, Australia
}

\begin{abstract}
Summary. - In this lecture we explain 1) the biochemical basis for photosynthesis and plant production and 2) the future demands on biomass for human use. Summing all physiological processes, the efficiency of converting solar energy into biomass is $<1.6 \%$ in the tropics, and between 0.4 and $0.8 \%$ for the temperate regions. In view of the present and future high demand on biomass for food, bioeconomics, fiber, construction material, only a relatively small fraction of plant production will be available for bioenergy. We estimate this fraction to be between 3 and $8 \%$ of the global energy demand by 2050. The contribution of bioenergy is at the higher end in tropical regions and in the less industrialized parts of the world, but may even be $<3 \%$ in industrialized nations.
\end{abstract}

\section{1. - Introduction}

The search for renewable sources for energy has been intensified over the past decade in response to concerns of national energy security and the awareness that burning of fossil fuels and land-use change cause greenhouse gas emissions that result in global climate change [1]. Thus, land-based biological strategies for climate mitigation are considered potential contributors to climate stabilization. However, to satisfy the growing demands for food, wood products, energy, climate mitigation and biodiversity conservation, all of which compete for biomass and the same terrestrial surface of the globe, the use of plant

This is an Open Access article distributed under the terms of the Creative Commons Attribution License 4.0, which permits unrestricted use, distribution, and reproduction in any medium, provided the original work is properly cited. 


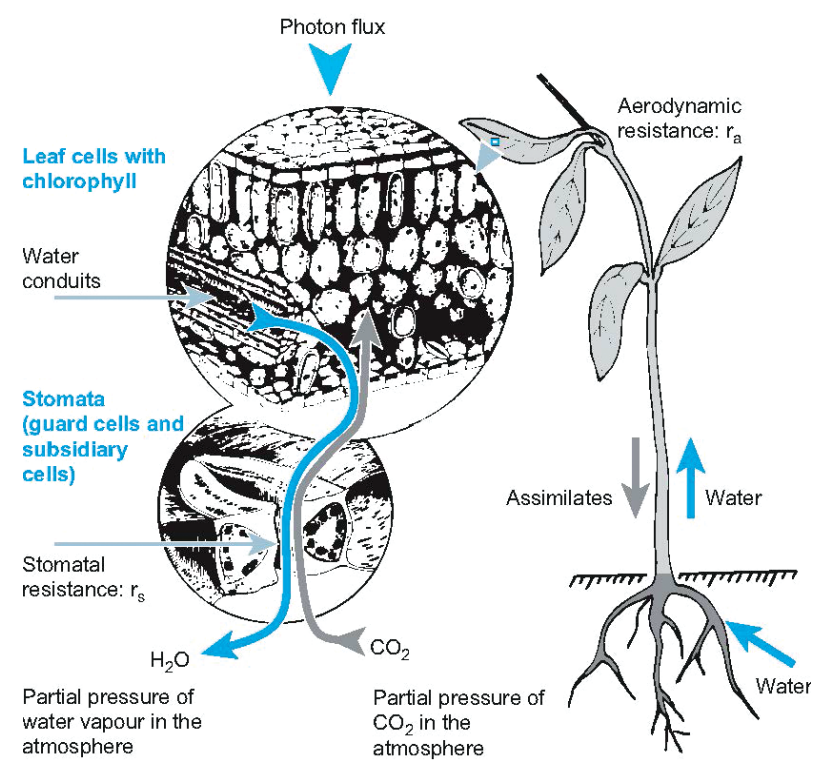

Fig. 1. - Functional design of a plant, including roots, stem and leaves, and the flow of assimilates and water with nutrients. In greater detail the structure of a leaf is shown with a separation of conducting system, the carbon assimilation tissue and the protective envelope of an epidermis (the skin of a plant) with specialized cells for gas diffusion [3].

products for energy must be placed in the context and priorities of multiple competing uses, and driven by high standards in sustainable development.

In the following we will start by explaining the biochemical basis of plant production in order to constrain the upper limit of biomass availability for energy production, and then assess the present use of biomass, and its future opportunities and limitations. In this short overview it will not be possible to provide enough details, but refer to common textbooks on plant physiology and plant ecology for the biochemical bases [2-4]. For the global assessment of bioenergy use we refer to the statement of the German National Academy of Sciences Leopoldina [5] and to the review by Canadell and Schulze [6] on climate mitigation.

\section{2. - Physiological basis of plant production}

In this section we like to introduce concepts of plant metabolism, the limitations of photosynthesis and respiration, and the regulation of growth and yields in order to give insight into some principles about plant functioning, including the regeneration of substrates in closed reaction cycles, the use of chemical energy via redox-systems, and the importance of membranes to separate charges.

Vascular plants have different organs for water and nutrient uptake, and for photosynthesis (fig. 1). Both organs are generally separated by a conducting system, the stem. 


\section{LNES 2014}

The system is designed to produce carbohydrates and amino acids for flowering and seed production. The same principle design holds for minute mosses and giant trees. We should be aware that we can only harvest the stem, the leaves and fruits, but not the roots, because this would destroy the habitat for growth, i.e. the soil.

Rainfall and drought are major problems for plant growth as known from watering the lawns of cities and gardens. It seems appropriate to start a description of plant production with an understanding of the relation between water vapor and carbon dioxide use. The diffusivity of $\mathrm{CO}_{2}$ in air is $0.14 \times 10^{-4} \mathrm{~m}^{2} \mathrm{~s}^{-1}$ and thus 4 orders of magnitude larger than in water $\left(0.16 \times 10^{-8} \mathrm{~m}^{2} \mathrm{~s}^{-1}\right)$, making life outside water attractive for plants. However, the $\mathrm{CO}_{2}$ gradient between the air and the leaf interior is in the order of $100 \mathrm{ppm}$, while the gradient of water vapor between water saturated cell walls of living cells and the surrounding air at average conditions of humidity is in the order of $12000 \mathrm{ppm}$. Thus, the efficiency of water use (including the differences in diffusivity of water vapor and $\left.\mathrm{CO}_{2}\right)$ is $12000 * 1.6 / 100$, and equals $192 \mathrm{~mol} \mathrm{H} \mathrm{H}_{2} \mathrm{O} / \mathrm{mol} \mathrm{CO}_{2}$. Thus plants must have access to large amounts of water in order to assimilate the atmospheric $\mathrm{CO}_{2}$ because there is no membrane that is permeable to $\mathrm{CO}_{2}$ but not to $\mathrm{H}_{2} \mathrm{O}$ due to the molar weight ratio of $44 / 18$, and there is no plant structure to store sufficient water. In this context it is interesting to note that present-day conditions are different for animals. At $20 \%$ oxygen in the air the $\mathrm{O}_{2}$ and the $\mathrm{H}_{2} \mathrm{O}$ gradient between the lung and the air is about $50000 \mathrm{ppm}$ for both molecules, which leads to a water use of only 1 mole $\mathrm{H}_{2} \mathrm{O}$ per $\mathrm{CO}_{2}$, and it decreases to 0.2 for cold-blooded animals. Thus, the availability of water is crucial for plants, which also cannot move, compared to animals, which also can hide by moving.

The production of biomass starts with the capture of solar energy by reducing "energy carrying" molecules in a so-called "light reaction". The products of this reaction are then available for reducing atmospheric $\mathrm{CO}_{2}$ in a second step of a so-called "dark reaction". During the light reaction electrons of the chlorophyll molecule are excited by photons (fig. 2), but only a narrow range of energy can be used for photochemistry. Blue light excites the electron to the second singlet stage, and the return reaction is too fast to be used photochemically. Only heat is produced. The red light excitement is not sufficient to bring the electron to the singlet stage, and the energy is lost by phosphorescence. Also, even if the electron reaches the first singlet stage, the energy may not be used because the photochemical acceptor is not ready for chemical use, or the protein is under repair from damage by previous reactions. In these cases the energy is also lost by heat or by fluorescence. Because of these limitations, the photosystem is designed to capture as many photons of a confined wavelength as possible, and lens-like antenna systems are produced for energy capture and transfer to a single reactive center for transferring the light into chemical energy.

The photochemistry contains two steps. Photosystem II (numbering according to the time of discovery) splits water into $\mathrm{O}_{2}$ and $\mathrm{H}^{+}$, with the electron being lifted from -1 to about $+0.9 \mathrm{eV}$ at a wavelength of $680 \mathrm{~nm}$. This energy is not sufficient to reduce the chemical energy carrier NADP (nicotinadenosindiphosphate) into NADPH. Thus Photosystem I is needed with light at $700 \mathrm{~nm}$ to produce $1.2 \mathrm{eV}$. The coordination between the two reactions is carried out by a Cytochrome-protein complex, that is swimming in the 


\section{EPJ Web of Conferences}

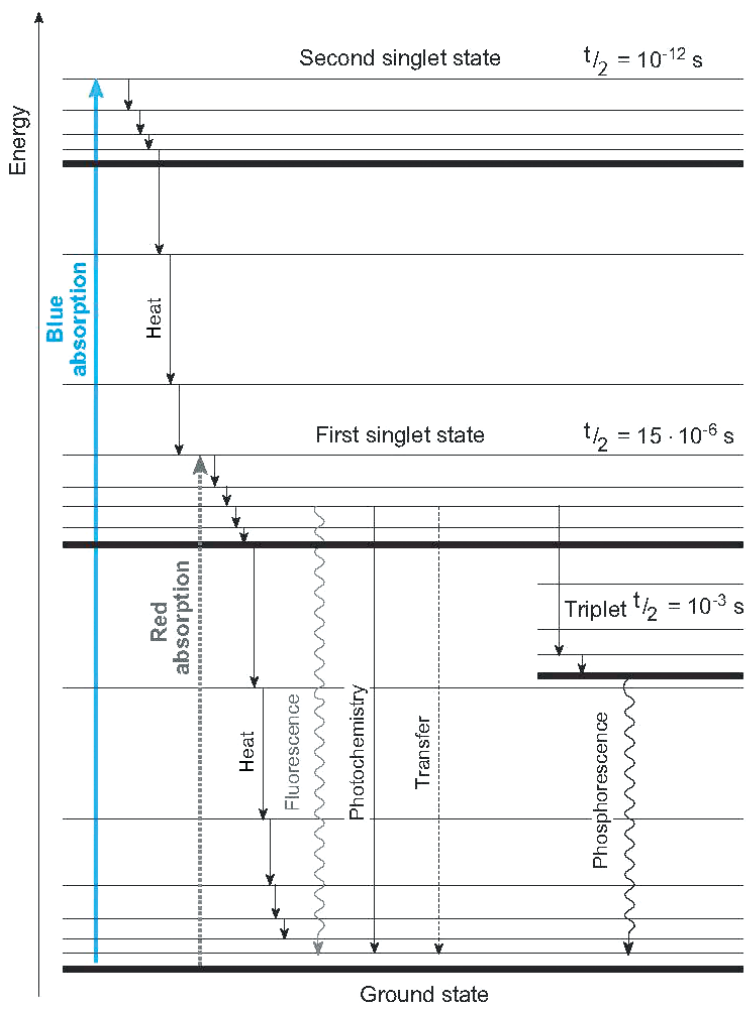

Fig. 2. - Light absorption and photochemical use at different wavelengths [3].

membrane and carrying the chemical energy between Photosystem II and I. This avoids overload in the electron transfer, but it costs time and a loss in efficiency. This loss has to be weighted against the risk of damaging the protein complex that captures the energy at 680 and $700 \mathrm{~nm}$. About $10 \%$ of the reaction centers are damaged at any time, and the efficiency of capturing light decreases with increasing levels of available light (fig. 3).

The reaction center of the photo-systems are a magnesium-nitrogen complex in the chlorophyll and an Fe-S complex for the NADP reduction. Additional minerals needed for this reaction are $\mathrm{Cu}$ for plastocyanin, $\mathrm{Zn}$ for scavenging oxygen radicals, and $\mathrm{Mn}$ for water splitting. Photosystem I also reduces nitrite and sulfite as part of the plant metabolism.

In the following dark reaction, 6 molecules of $\mathrm{CO}_{2}$ are reduced to form one molecule of glucose. This reaction requires the energy of 12 molecules of NADPH, plus 12 protons, $\mathrm{H}^{+}$, and 18 molecules of ATP (adenosintriphosphate). In this reaction $\mathrm{CO}_{2}$ binds initially to a lysin- $\mathrm{NH}_{3}$ complex forming a carbamat which is activated by $\mathrm{Mg}$. The initial product is a phospho-glycerat which is formed from ribulose-bis-phosphate, RuBP. The glycerate is reduced to triosephosphate the earliest photosynthetic product. The triosephosphate can be further condensed to fructose and starch in the chloroplast, or it can be condensed to sucrose and exported to the conducting system of the plant. 


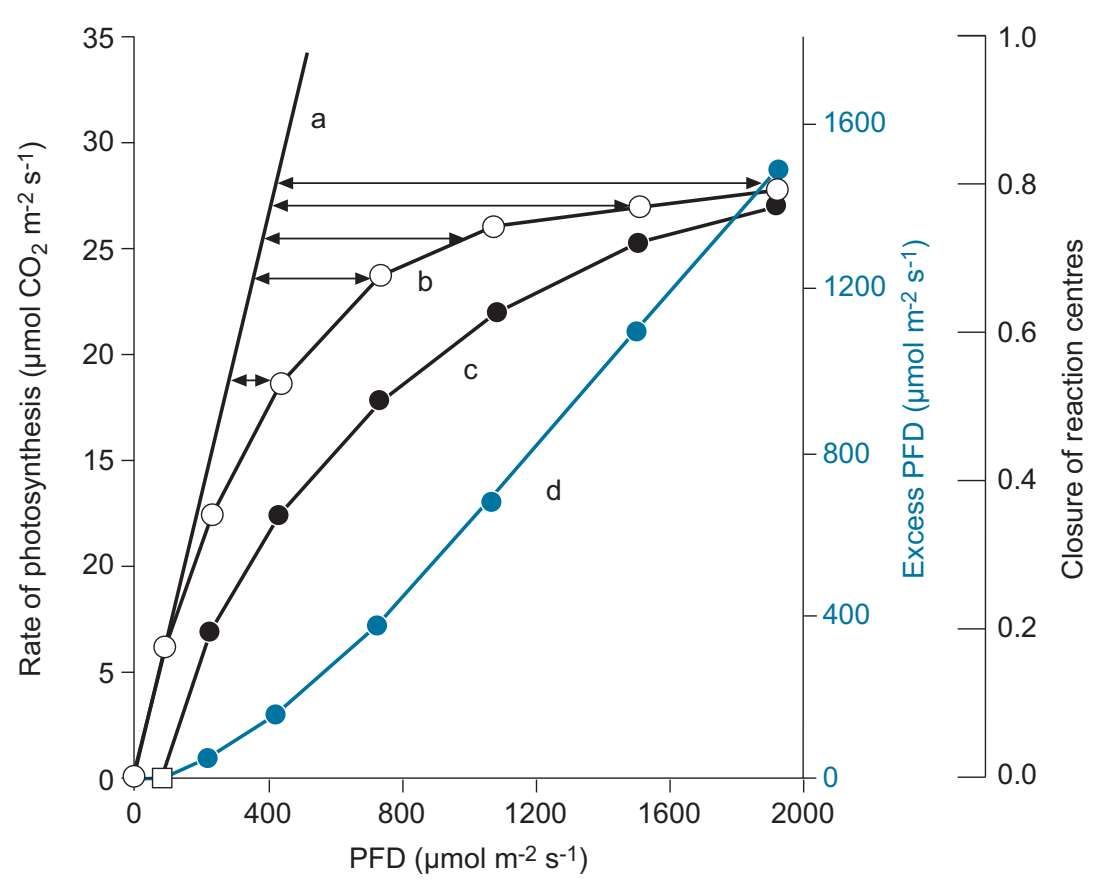

Fig. 3. - Light saturation curve of photosynthesis showing (curve b) the rate of $\mathrm{CO}_{2}$ fixation in response to photon flux density, PFD. a) Linear response of photosynthesis with increasing light at low PFD. c) Calculated time of transfer of electrons from PSII including repair of damage by light. d) Excess light energy [3].

All plant cells, that do not contain chloroplasts, must generate their energy from the break-down of saccharine via formation of organic acids and the reduction of ATP and $\mathrm{NADH}$ as universal chemical energy carriers in other biochemical reactions.

Besides light, the availability of $\mathrm{CO}_{2}$ gas is one of the limiting substances in photosynthesis. Figure 4 summarizes the complicated interactions by showing the rate of $\mathrm{CO}_{2}$ assimilation at increasing atmospheric $\mathrm{CO}_{2}$ concentration. We distinguish between so-called C4-plants, where $\mathrm{CO}_{2}$ is initially fixed as organic acid and reduced to carbohydrates in a second step after concentrating $\mathrm{CO}_{2}$ in specific cells, and C3-plants, which lack the $\mathrm{CO}_{2}$-concentration mechanism. Here we can deal only with the $\mathrm{C} 3$-plants in detail. $\mathrm{CO}_{2}$ assimilation increases with atmospheric $\mathrm{CO}_{2}$ concentration if the $\mathrm{CO}_{2}$-binding enzyme is limiting but RuBP is available. The response saturates at about $500 \mathrm{ppm}$ when the regeneration of $\mathrm{RuBP}$ becomes limiting.

The response operates at a lower $\mathrm{CO}_{2}$-concentration than in the atmosphere, because $\mathrm{CO}_{2}$ enters into the leaf via the stomata cells, which are openings in the epidermis allowing gases to pass (see fig. 1). This restriction in the diffusion can be expressed as a conductance, $g_{s}$, which reduces the mesophyll internal $\mathrm{CO}_{2}$ concentration, $C_{i}$, proportional to the pore size of the stomatal cell pair. This conductance is adjustable. 


\section{EPJ Web of Conferences}

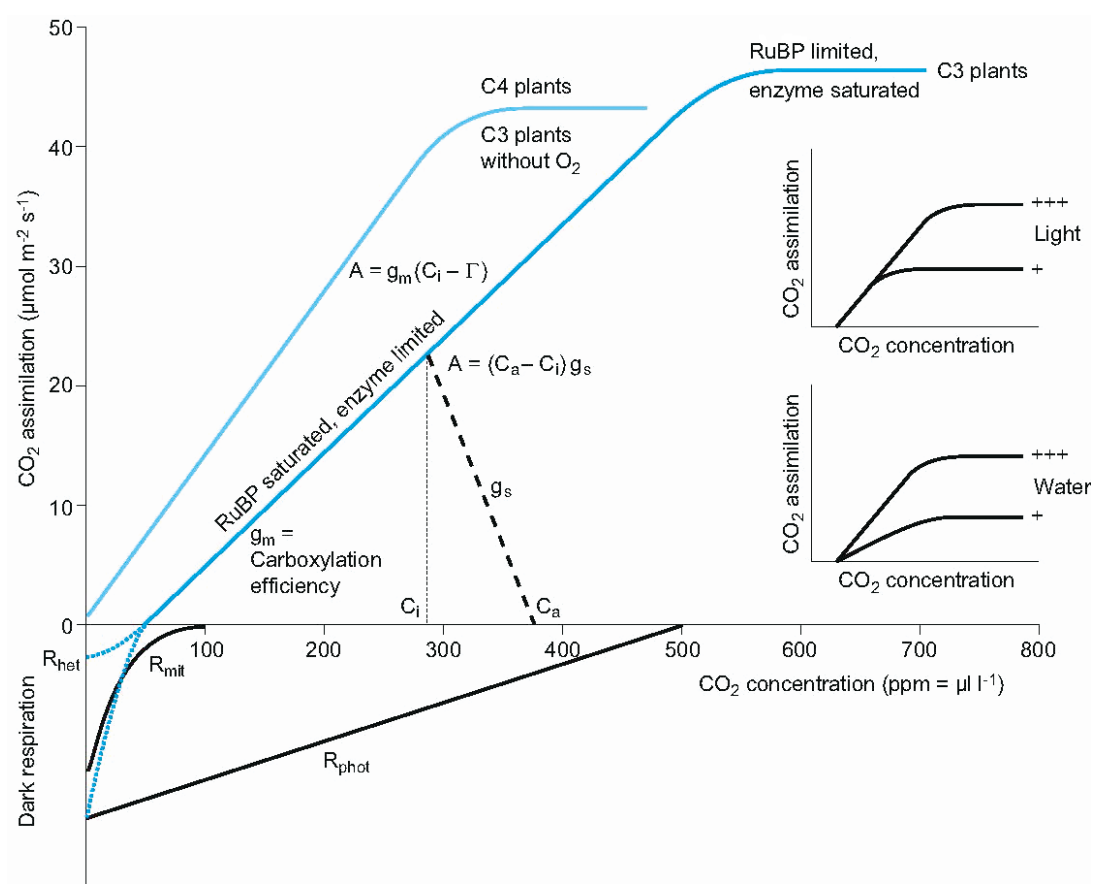

Fig. 4. - Schematic representation of the response of $\mathrm{CO}_{2}$-assimilation in $\mathrm{C} 4$ and C3-plants to the $\mathrm{CO}_{2}$ concentration in the atmosphere. Positive values represent $\mathrm{CO}_{2}$ uptake, negative values represent $\mathrm{CO}_{2}$ emission. The inserted figures show that changes in light climate change the saturation point of the $\mathrm{CO}_{2}$-fixation, while limitations in water change the slope of the reaction. For further explanations see text [3].

It is interesting to note that $C_{i}$ is under most environmental conditions adjusted to be at about $50 \%$ of the maximum capacity of the enzyme system. Most enzymes in metabolism operate at such low rate, because it gives sufficient flexibility to cope with variations in light and thus avoid damage. The conditions of low $\mathrm{CO}_{2}$ concentration are highly uncertain and dependent on the so-called rate of photorespiration (a process forming amino-acids) and dark respiration.

The regulation of the diffusive conductance of the guard cells is very complicated. Mechanistically it is an osmotic response to $\mathrm{K}^{+}$being carried into or out of these cells, a high osmotic pressure causing the cells to open the stomatal pore, allowing $\mathrm{CO}_{2}$ and $\mathrm{H}_{2} \mathrm{O}$ diffusion, and low osmotic pressure causing the stomatal pore to close. There is no unifying concept to describe this regulation. The stomatal pore is adjusted directly by light, temperature, and air humidity, and indirectly by metabolic signals, such as abscisic acid, which can originate from the metabolism in the root in response to dry soil.

Even though the biochemistry in the leaf is the primary source for carbohydrates, it does not determine the total amount of carbohydrates that are available to a plant because the plant individual has restrictions to expose leaves to the light (too many leaves 
LNES 2014

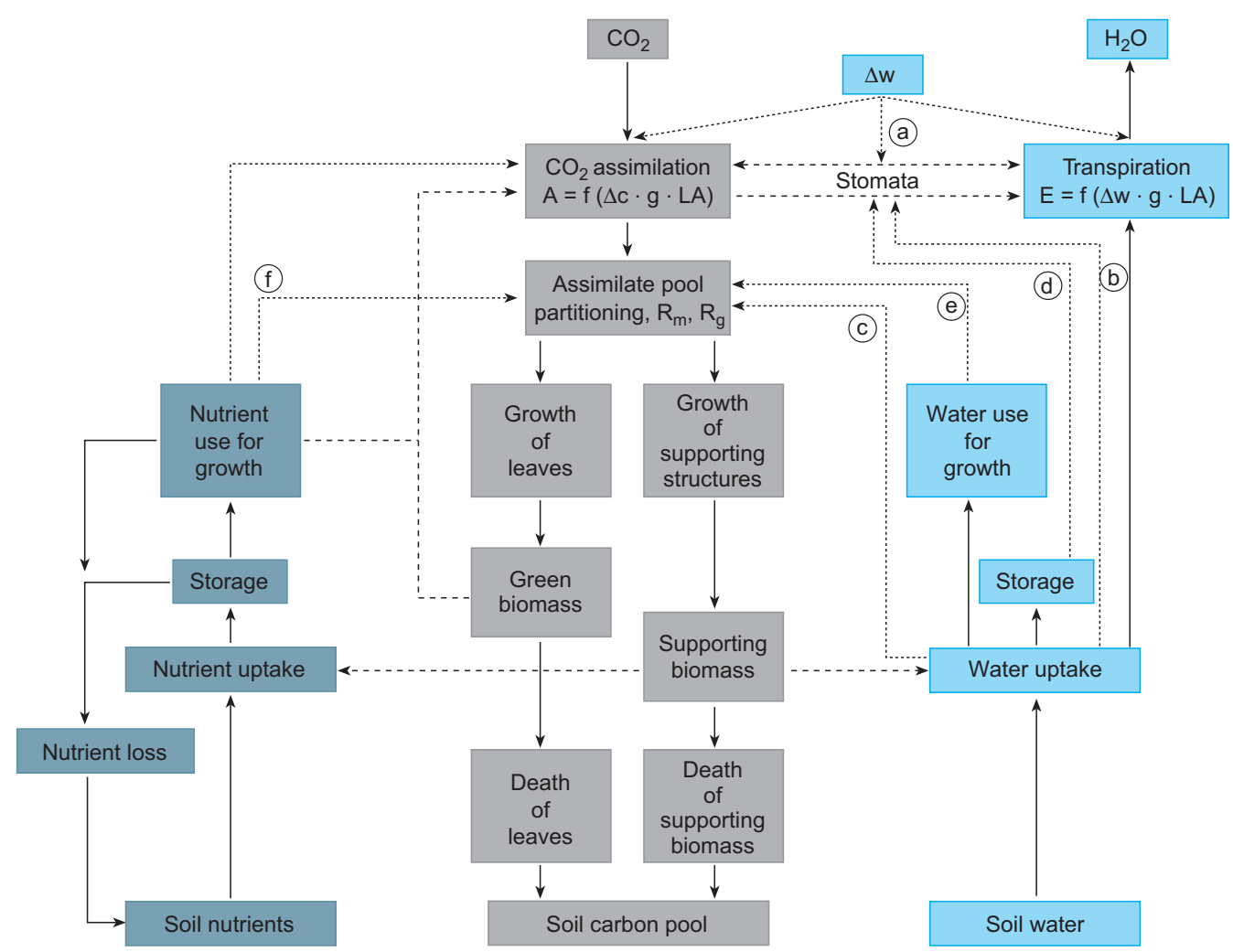

Fig. 5. - Schematic model of the interactions and controls between water- nutrient- and carbonrelations at the whole plant level. Fluxes of materials are shown by solid lines, controls are indicated by dashed lines. Air humidity as indicated by $\Delta \mathrm{w}$ represents the saturation deficit between leaf mesophyll and air. The equations in the assimilation and transpiration boxes represent the diffusion of $\mathrm{CO}_{2}$ and $\mathrm{H}_{2} \mathrm{O}$ through the stomata, as represented by a conductance $\mathrm{g}$, and the leaf area, LA. Small letters in circles represent (a) controls by the atmosphere, (b) and (c) by the water supply to the root, and (d) by water and (f) by nutrient deficits in cells [3].

would shade each other) and to maintain a balance between the water and nutrient supply from the root and the carbohydrate supply from the leaf, considering also the senescence of various organs. At this point we can only show a conceptual model of these mutual limitations (fig. 5). Water and nutrients in the soil promote leaf growth depending on the supply by the root. On the contrary leaf growth and its photosynthesis supply the carbohydrates to grow more new leaves and roots, where the "decision" to grow a new leaf also depends on the amount of existing biomass in terms of energy demand (by maintaining respiration) and the mutual self-shading of new leaves over old leaves.

The understanding of the carbon-relations of an individual plant is not enough to understand the interactions between plants in a plant community and between plants and soils in an ecosystem. It would go beyond this lecture to explain all these fluxes in 


\section{EPJ Web of Conferences}
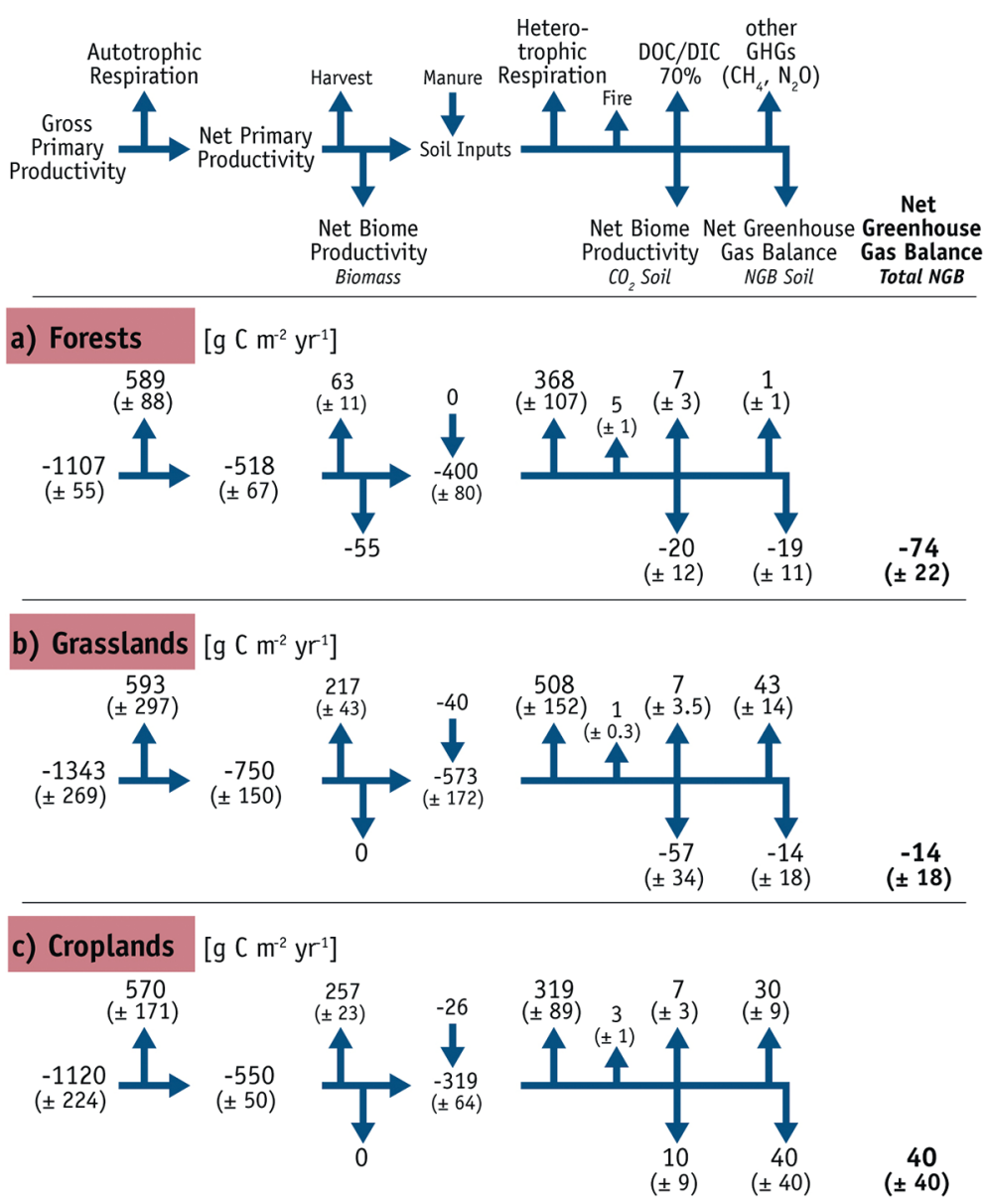

Fig. 6. $-\mathrm{CO}_{2}$ fluxes at the ecosystem level, for explanation see text $[7,8]$. Arrows pointing to the top indicate $\mathrm{C}$ fluxes to the atmosphere, while arrows pointing to the bottom indicate $\mathrm{C}$ fluxes to the soil or into biomass.

detail, but it is important to understand, that photosynthesis is only one of many fluxes at the ecosystem level (fig. 6), and one that is still far from telling the amount of biomass that ultimately will be produced.

Input to the ecosystem is "gross primary productivity", which is equivalent to photosynthesis, but calculated by assumptions about plant respiration in the light. About $50 \%$ of the carbohydrates produced in this way are used by the plant itself during autotrophic respiration, i.e. respiration of living plant cells that do not contain chloroplast. The outcome of this plant internal carbon balance is the "net primary production", which is equivalent to plant growth. The soil with its input of organic matter from litter and animals feeds the microbial communities in the soil which emit carbon dioxide to the atmosphere, i.e., heterotrophic respiration. Carbon is also emitted to the atmosphere by 


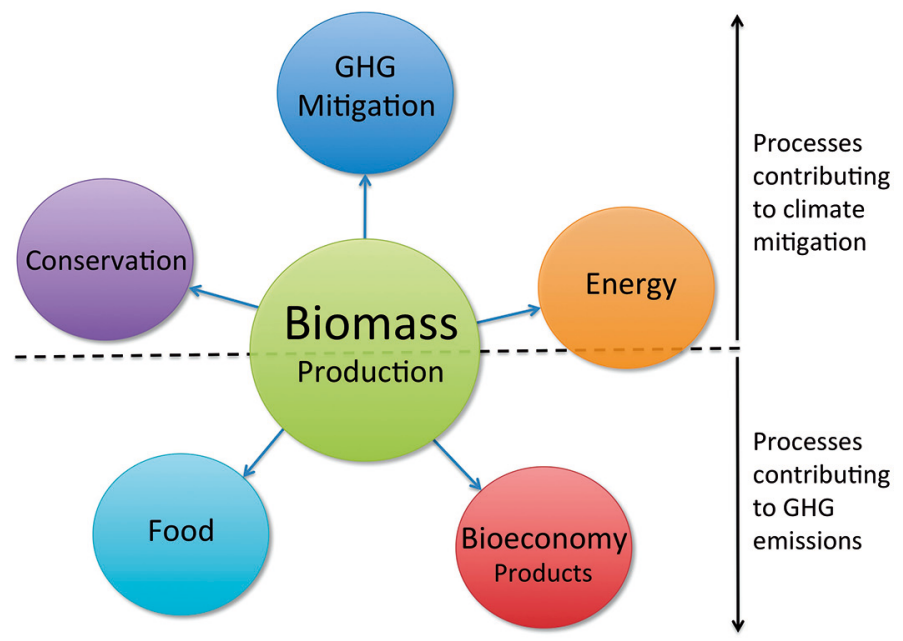

Fig. 7. - Demands on biomass from multiple sectors: Conservation, Greenhouse-gas mitigation and part of energy production would contribute to climate mitigation, while food production and bioeconomics cause greenhouse-gas emissions and thus enhance climate change [6].

fires and lost by dissolved organic and inorganic carbon to ground water. The combination of all these fluxes, including plant harvest by animals and humans, results in the net biome production as the landscape level C-balance. The metabolism of microorganisms inside other organisms (ruminants) and in the soil cause other non- $\mathrm{CO}_{2}$ greenhouse gas emissions to the atmosphere, mainly $\mathrm{CH}_{4}$ and $\mathrm{N}_{2} \mathrm{O}$. Only after accounting for these emissions we derive the resultant Greenhouse Gas Balance, NGB, of an ecosystem.

Taking net plant production (NPP) as a basis (about $50 \%$ of photosynthesis), which is of interest for bioenergy, Larcher [4] derived an efficiency of photon use of the terrestrial global plant cover to be $<1.6 \%$ in the humid tropics, 0.4 to $0.8 \%$ in the temperate zones, and $<0.02 \%$ in the arid regions. Thus, the global average photon use efficiency is $<1 \%$. At the ecosystem level based on NBP the photon use efficiency is $<0.1 \%$.

\section{3. - The supply and use of biomass for energy}

Based on the foregoing analysis we could stop here and conclude that burning of biomass to produce energy is such an inefficient use of solar energy, that it is clearly not an activity that should be pursued. However, this is not the reality. Governments around the world see domestic bioenergy production as a key development in achieving national energy security, especially for liquid fuels. In developing countries and also in some developed countries there is an increase use of firewood (and pellets) for home heating and luxurious open fireplaces. Thus, we will further assess the constraints of land-use and biomass production.

There are conflicting demands on biomass use (fig. 7), some of which contribute to cli- 


\section{EPJ Web of Conferences}

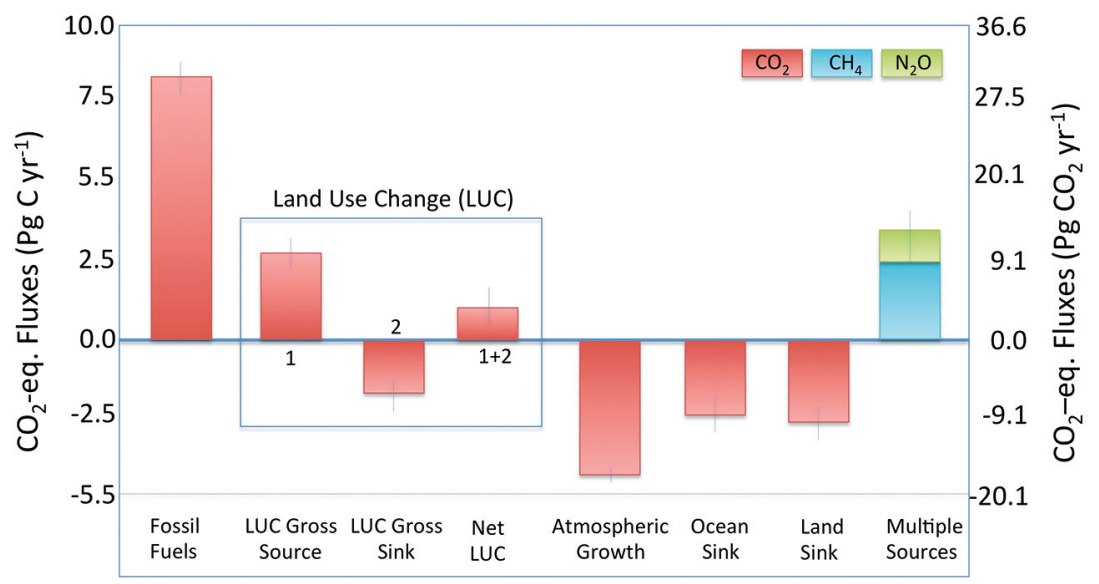

Fig. 8. - Fluxes of global greenhouse-gas fluxes as averaged for the period 2003 to 2012 [6].

mate mitigation, other enhance climate change. The contribution of the energy-sector is ambiguous, depending on the associated greenhouse-gas (GHG) balance [9]. The multiple demands on land and biomass are closely linked. For example, increased food production causes GHG emissions which in turn produces climate change, may require additional land, which in turn may reduce the natural $\mathrm{CO}_{2}$ sinks, and therefore further accelerating climate change. The reverse would also apply. GHG emissions include mainly $\mathrm{CO}_{2}, \mathrm{~N}_{2} \mathrm{O}$ and $\mathrm{CH}_{4}$. Conservation could reduce deforestation, but full protection also reduce the net ecosystem carbon uptake due to enhanced respiration of dead wood and decaying biomass [10]. Bioeconomics intends to replace fossil-fuel-based products, but the production of the required biomass could either cause land-use change or GHG emissions.

The magnitude of the resultant GHG fluxes are summarized in fig. 8 as averaged over 10 years (2003 to 2012). The dominating role of $\mathrm{CO}_{2}$ emissions is obvious. Land-use change (LUC) also results in net $\mathrm{CO}_{2}$ emissions, even though this is the result of two larger components, namely emissions from clearing land and $\mathrm{CO}_{2}$ uptake from regrowth on abandoned land. Both types of emissions are balanced by the growth of $\mathrm{CO}_{2}$ stored in the atmosphere, by uptake of the oceans, and by uptake of the land surface, including the production of biomass for human use. It is remarkable that the global land- $\mathrm{CO}_{2}$-sink is exceeded by carbon-equivalent emissions of $\mathrm{CH}_{4}$ and $\mathrm{N}_{2} \mathrm{O}$, with $\mathrm{CH}_{4}$ emissions mainly caused by meat production, and $\mathrm{N}_{2} \mathrm{O}$ emissions caused by fertilizer application to grow biomass. Thus, reducing GHG emissions should be a top priority in climate mitigation efforts. In Europe, Germany, Benelux-states, northern France and southern England are the regions with the largest GHG emissions [7]. Globally, China and USA are the nations with the highest GHG emissions, exceeding all other nations [11].

Assessing the efficacy and desirability of different land-based biological climate mitigation is not straightforward (fig. 9), because any activity has positive and negative 
LNES 2014

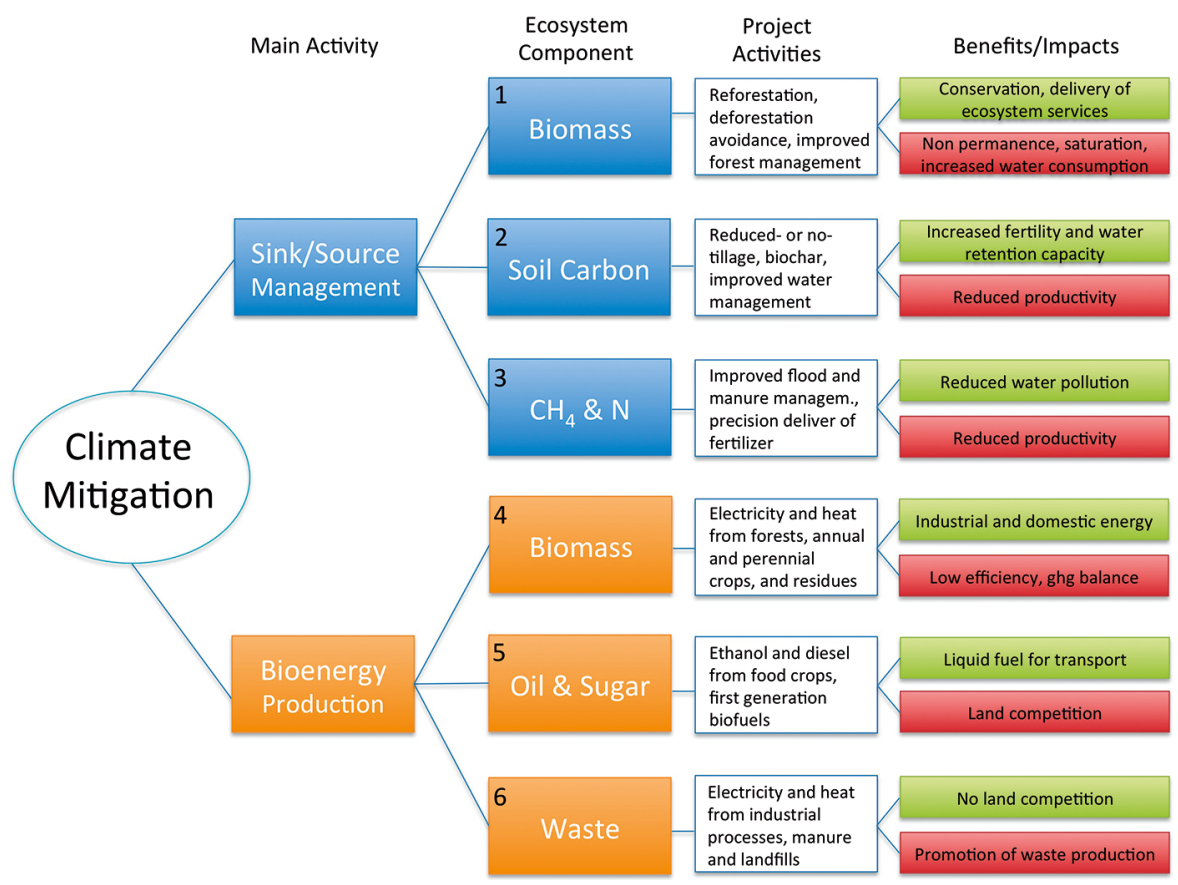

Fig. 9. - Pros and cons of various options of land-based biological climate mitigation activities [6].

effects [6]. There are two types of climate mitigation strategies. First, the management of sinks and sources via increasing carbon sinks and decreasing carbon GHG sources, which would compensate fossil-fuel emissions. Second, the management of bioenergy production to replace fossil-fuel energy sources and so decreasing GHG emissions. The source/sink management would enhance storage in biomass and soils, mainly by conservation, or the reduction of non-carbon-GHG emissions. The main drawback of all of these activities would be a reduced productivity, the likelihood of a non-permanence, the spread of pests and diseases, and the saturation of sinks (i.e. the activity will cease to be effective). The bioenergy production includes biomass for burning, and for the production of oil and methanol; this includes the use of waste and forest/agriculture residues in modest amounts. The extensive use of energy crops has the caveats that the production of energy and food might be in competition for land. Waste use has the caveat of implicitly promoting waste production.

A global assessment of the potential of energy crops estimates that under the desirable strict regulations for a sustainable deployment of cropping and production, bioenergy could supply between 3 and $8 \%$ of the primary energy consumption by 2050 [6]. The assessment excludes previous larger estimates with unsustainable practices including further deforestation, competition with food production, or heavy reliance on forestry and agricultural residues that are necessary locally to maintain soil fertility and structure. 


\section{EPJ Web of Conferences}

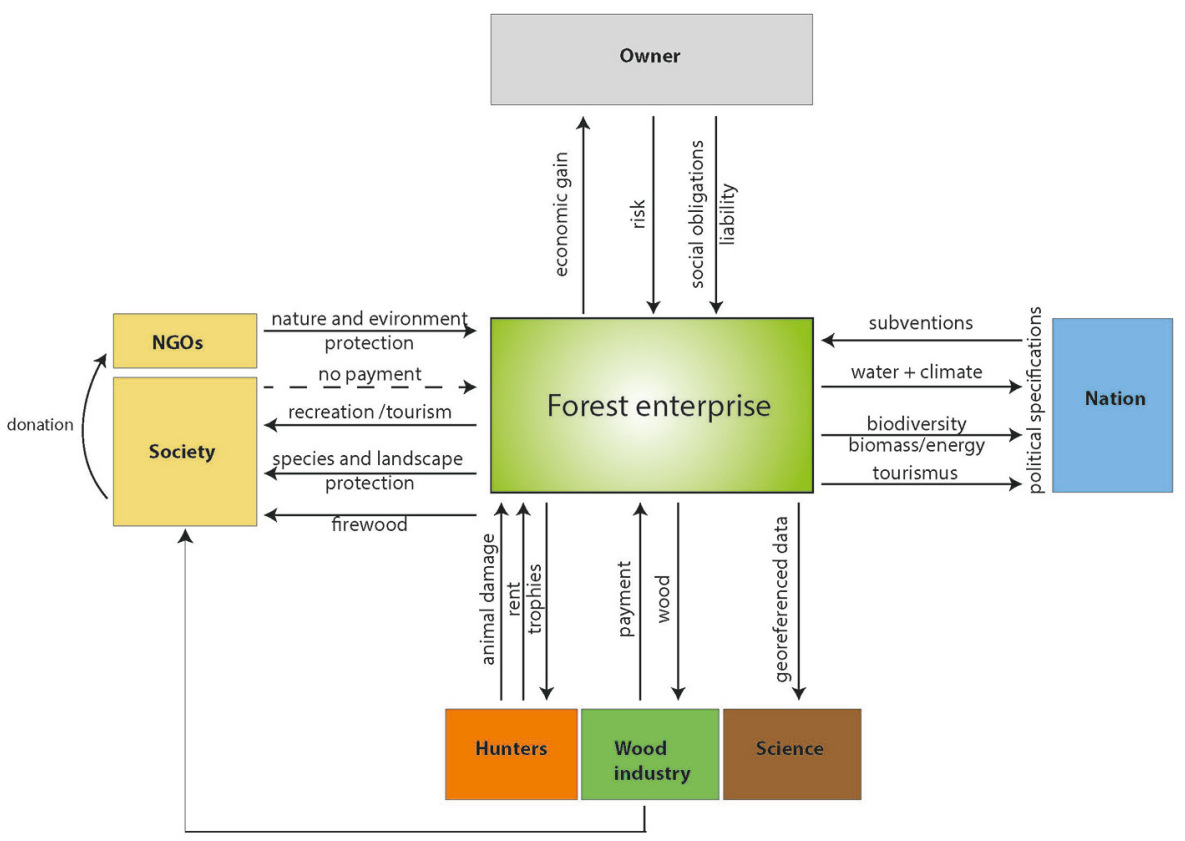

Fig. 10. - Who demands what from a forest enterprise [12].

\section{4. - A regional example of the constraints of GHG emission management: Germany}

In the following we like to explore the chances and limitations of bioenergy production in forestry and in agriculture, taking the situation of Germany, the main fossil-fuel emitter of Europe, as an example.

In forestry, even though wood production is the main commercial objective of a land owner, there are numerous additional non-monetary demands by society (fig. 10), ranging from recreation via hunting to enabling the production of drinking water [12]. In this context it is interesting to explore, who represents "society". To a large extent the representation is by Non-Governmental Groups (NGOs) that demand high stakes on those other societal benefits (e.g. abandoning harvest on $10 \%$ of German forest land and putting it into wilderness). It is quite obvious, that all of these societal demands affect climate mitigation in positive and negative ways. There are also embedded conflicts, such as the damage by high deer populations, as favored by hunters [13], and wood production, and the conservation of biodiversity.

In terms of wood production, again, there are various options [14]. The traditional silvicultural practice was a rotation forestry, where stands of different age classes grew up to about 100 yrs until harvest by clear-cut (fig. 11). This practice has been abandoned by the request of the broader public opposing to possible ecological consequences of clear cuts, even though these consequences are scientifically debatable [15]. Thus forests are 


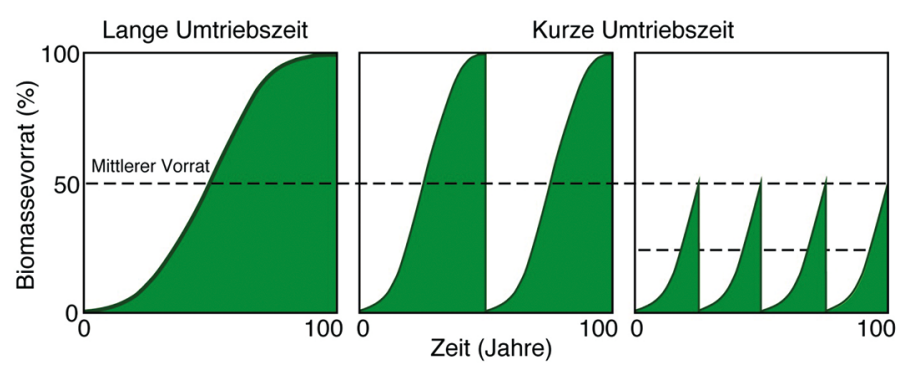

Fig. 11. - Options of wood-production in Germany [14].

re-structured into selective-cutting, which is not included in fig. 11 for simplicity reasons. One possible way to increase productivity is the plantation of new species with higher growth rate, and which could be harvested after $50 \mathrm{yr}$ rotation. One possibility to achieve this would be the plantation of Douglas fir in Germany. However, the conservation administrations under the pressure of NGOs declared Douglas fir as an invasive alien species, which should be eradicated and trade was threatened to be condemned [16]. Thus, there are emotional pressures, which oppose climate mitigation. The alternative would be to fertilize native species, with associated emissions of GHGs [14], or the conversion of forest into short-rotation coppices, which was historically used for firewood, but which proved to be non-economic and unsustainable due to the additional uses for grazing of domestic animals and to grow barley the year after coppicing. The consequences of this management type can be visited in Kosovo, former Yugoslavia [13].

Forest enterprises sell wood to a wood market, and the demand drives the production. One major problem we observe is the increasing demand for firewood in Germany caused by multiple reasons, such as the increasing cost of fossil fuel for heating, the luxury burning in open fireplaces, and the increasing awareness of the public about global change and the willingness to help mitigation with using renewable resources for heating. The total demand of firewood has increased beyond the possible supply by German forestry. Thus, prices have increased almost 10-fold over the past 5 years, and the incentive of using fertilizer in forestry increased with the associated $\mathrm{N}_{2} \mathrm{O}$ production [17]. Firewood is presently imported to Germany from North America and Russia [18]. In addition, burning wood is not at all C-neutral due to non- $\mathrm{CO}_{2}$ GHG emissions [19].

In conclusion, we may summarize the forest sector in Germany as following. Wood production is renewable, but wood is not unlimitedly available and the use of wood as energy source causes additional non- $\mathrm{CO}_{2}$ GHG emissions. The public is increasingly concerned about global climate change, and willing to pay extra for "green" energy, to use wood for construction (Douglas fir because of its durability) and heating. The desire for living environmentally friendly leads to increased use of forest products and to limited supply. The demand has increasingly to be met by imports from outside Germany. At the same time, the public objects against the growth of new forest species in German forests (e.g., Douglas fir) and requests more area for recreation, nature conservation, deciduous forest, and deadwood for homing of dead-wood beetles. The "green" life- 


\section{EPJ Web of Conferences}
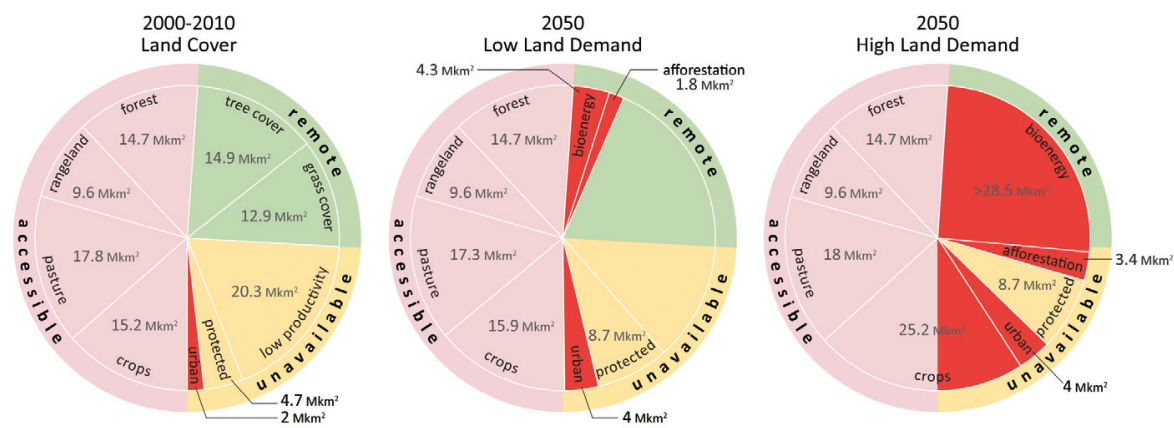

Fig. 12. - Current and future global land demand [6].

style contradicts the demands for putting forest into a conservation status and personal recreation. Thus, wood production for climate mitigation in Germany is being outsourced to other countries, and personal demands for recreation take priority.

In agriculture the situation is more concerning because Germany is purposefully not accounting non- $\mathrm{CO}_{2}$ greenhouse gas emissions, the most important GHG in agriculture. This is based on the exemption of the EU Common Agricultural Practice for food production, even though about $25 \%$ of the agricultural land is presently used for industrial products, such as bioenergy. The non- $\mathrm{CO}_{2}$ GHG emissions are high. 50\% of the European $\mathrm{CH}_{4}$ emissions originate from animal husbandry, $70 \%$ of the $\mathrm{N}_{2} \mathrm{O}$ emissions originate from cropping, and $90 \%$ of the $\mathrm{NH}_{3}$ emissions are of agricultural origin [8]. Part of the problem is that large amounts of fodder are imported to achieve a higher meat and milk production. Only about $3 \%$ of the fed nitrogen-fodder remains in milk and meat, and the rest is excreted, and thus contributes to GHG emissions and to nitrate pollution in ground-waters. Biofuel production of about 1.7 million tons of carbon (MtC), meat production of about $1.6 \mathrm{MtC}$ and milk production of about $1.5 \mathrm{MtC}$ (in total about $5 \mathrm{MtC}$ production) require $5 \mathrm{MtC}$ of high $\mathrm{N}$-fodder imports and about $75 \mathrm{MtC}$ rough fodder for ruminants, and result in $60 \mathrm{MtC}$-equivalent $\mathrm{CH}_{4}$ and $40 \mathrm{MtC}$-equivalent $\mathrm{N}_{2} \mathrm{O}$ production, with a large fraction of the products being exported [20,7].

DiLucia et al. [9] summarized the mitigation potentials of liquid biofuels for Europe and concluded that neither sugarcane, wheat, maize, soja nor rapeseed meets the EU efficiency targets for replacing fossil fuels. The present consumption can only be met by imports to Europe [18]. Obviously, the industrial agriculture in Germany is unsustainable, and it contributes to rather than mitigates the global climate change. The production of agricultural goods is increasingly based on land outside Germany.

\section{5. - Global land area requirements}

The global climate debate is centered mainly on mass balances. Concerning the contribution of land, however, there is the need to consider that the cultivation of products requires land area (fig. 12). Presently, about $50 \%$ of the global land surface is used by agriculture and forestry to grow products for human use. The rest of the land is either 
too remote for management (e.g. remote tundra areas) or it is unavailable (e.g. alpine regions or deserts). It is evident, that even today the so-called remote and unavailable areas are extensively grazed by nomadic people. With the given distinction we like to separate land with commercial harvest of biomass from land that is remaining quasi "natural", except for cities.

Projecting the land demands into the future, one scenario is that land will be taken into commercial use by each sector individually, i.e. agriculture, bioenergy, bioeconomics and forestry. In this case the demand will be so large, that the area-equivalent of managing most of the remote and unavailable land would be needed, which is not possible, due to the environmental conditions of such regions (permafrost, salinity, rock-surfaces). A composite of all current aspirational land demands from multiple sectors is estimated to be 3 to 7 times bigger than the land considered being available under various definitions [6]. Alternatively, the land demand could be confined by sustainable land management, which includes an intensification of plant cultivation on the one hand (e.g. closing the yield gap in non-industrialized countries) but a reduction of GHG emissions on the other. GHG emissions could be reduced by application of fertilizer according to the demand for growth by the plant cover. It is clear that sustainable land management and intensification of production on existing land will not be acceptable by many groups of the society, but it is the same society which creates the demands and buys these products. Also, commercial incentives exist, that use land wherever possible, to produce products that are paid by developed countries. The encroachment of oil palm into rainforests of Africa and Southeast Asia to produce biodiesel for industrialized nations may be taken as example [21]. In addition, developed nations tend to increase demand for recreation over land for climate mitigation $[22,23]$.

\section{6. - Conclusion}

The mitigation potential of land-based carbon mitigation is large with respect to reducing non- $\mathrm{CO}_{2}$ GHG emissions, even though the contribution to substitute fossil fuels for energy production is low. Canadell and Schulze [6] estimated that only about 3 to $8 \%$ of the global energy requirement can be delivered from biomass. In view of the fact that more people want to participate in the life-style of present industrialized nations, the growing energy demand can only be supplied by technical processes rather than by biological production.

\section{REFERENCES}

[1] IPCC, Global Climate Change, The Scientific Basis (Cambridge University Press, Cambridge) 2014.

[2] Lambers H., Chapin III F. S. and Pons T. L., Plant Physiological Ecology (Springer Verlag, New York) 1998.

[3] Schulze E. D., Beck E. and Müller-Hohenstein K., Plant Ecology (Springer Verlag, Heidelberg) 2002. 


\section{EPJ Web of Conferences}

[4] Larcher W., Physiological Plant Ecology, 4th edition (Springer Verlag, Heidelberg) 2003.

[5] German National Academy of Sciences Leopoldina, Bioenergy - chances and Limits (Halle (Saale)) 2012.

[6] Canadell J. G. and Schulze E. D., Nat. Commun., 5 (2014) 5282.

[7] Schulze E. D., Luyssaert S., Ciais P., Freibauer A., Jannsens I. A., Soussana J. F., Grace J., Levin I., Thiruchittampalam B., Heimann M., Dolman A. J., Valentini R., Bousquet P., Peylin P., Peters W., Rödenbeck C., Etiope G., Vuichard N., Wattenbach M., Nabuurs G. J., Poussi Z., Nieschulze J. and Gach J. H., Nat. Geosci., 2 (2009) 842.

[8] Schulze E. D., Ciais P., Luyssaert S., Schrumpf M., Janssens I. A., Thiruchttampalam B., Theloke J., Saurat M., Bringezu S., Lelieveld J., Lohila A., Rebmann C., Jung M., Bastviken D., Abril G., Grassi G., Leip A., Freibauer A., Kutsch W., Don A., Nieschulze J., Börner A., Gash J. and Dolman A. J., Global Change Biol., 16 (2010) 1451.

[9] Di Lucia L., Ahlgren S. and Ericsson K., Environm. Sci. Policy, 16 (2012) 9.

[10] Schulze E. D., Aas G., Grimm G. W., Denk T., Gossner M. M., Kühn I., SchererLorenzen M., Walentowski H., Bouriaud O. and Luyssaert S., submitted to Eur. J. For. Res. (2014).

[11] Global carbon Project (2013) Global Carbon Altas, CSIRO, Canberra http: www.globalcarbonatlas.org.

[12] Schulze E. D. and Schulze I., AFZ-Der Wald, 6 (2013) 7.

[13] Bouriaud L., Nichiforel L., Nunes L., Pereira H. and Bajraktari A., Biomass Bioen., 67 (2014) 425.

[14] Schulze E. D. and KöRner C. H., "Nettoprimärproduktion und Bioenergie", in: Leopoldina Statement: Bioenergy - Chances and Limits. (2012) pp, 90-101, ISBN 9783-8047-3081-6.

[15] Schulze E. D., Bouriaud L., Bussler H., Gossner M., Walentowski H., Hessenmöller D., Bouriaud O. and Gadow K. von, Web Ecol., 14 (2014) 3.

[16] Schulze E. D., Bouriaud O., Wäldchen J., Eisenhauer N., Walentowski H., Seele C., Heinze E., Pruschitzki U., Dănilă G., Marin G., Hessenmöller D., Bouriaud L. and Teodosiu M., Ann. For. Res., 57 (2014) http://dx.doi.org/10.15287/ afr.2014.273.

[17] Papen H. and Butterbach-Bahl K., J. Geophys. Res., 104 (1999) 18487.

[18] Edenhofer O., Pichs-Madruga R., Sokona Y., Seyboth K., Matschoss P., Kadner S., Zwickel T., Eickemeier P., Hansen G., Schlömer S. and von Stechow C. (Editors), Renewable energy sources and climate change mitigation (SRREN), Special Report of IPCC, (Cambridge University Press, Cambridge) 2011.

[19] Hahomsen G. and Kvingedal E., Utslipp til luft fre vedfyring I Norge - utslippsfaktorer, ildstedsbestand og fyringsvaner (Statistics Norway, Oslo, Kongsvinger) 2010, ISBN 82-5374994-5.

[20] Hemmerling U., Deutsch. Bauernkur., 9/12 (2012) 4.

[21] Carrasco L. R., Larosa C., Milner-Gulland E. J. and Edwards D. P., Science, 346 (2014) 38.

[22] Schulze E. D., Polit. Ökol., 132 (2013) 63.

[23] Schulze E. D., AFZ-Der Wald, 17 (2013) 31. 